\title{
Preface: Regional Patterns in the China War, 1937-1945
}

$\mathrm{T}$ HE TENSIONS IN EAST ASIA that now seem most dangerous, those between North and South Korea and between mainland China and Taiwan, may well be resolved within the next few decades. The tension in the region that is likely to remain well beyond the next few decades is that between the two great powers, China and Japan. Will the rivalry between these two nations intensify as they compete to acquire oil and other natural resources, sell high-technology products and automobiles, and gain influence in Southeast Asia and elsewhere? Can they make concessions to each other to achieve peace while keeping the support of their own people? Will their search for security lead them to expand their production of weapons, setting off an arms race and conflict over disputed territories? Or will the two countries in the decades ahead contain their rivalry and work together for their common interests as Germany and France did after World War II?

How China and Japan deal with each other is inextricably linked to the question of how they look at their most bitter conflict, the China War, I93I-45.* The first conflict between China and Japan, the Sino-Japanese War of $1894-95$, was fought on the periphery of China on a small scale over a brief period of time. The China War brought the conflict to all major regions of the country over a long period of time and resulted in tens of millions of casualties. During the China War, death and destruction were on a scale beyond anything the Chinese had ever experienced, not only from the fighting itself but also from the dislocations of people, of transport routes, and of sources of livelihood.

The war divided families and communities. It created splits between people who cooperated more with the Japanese, those who cooperated

* In this volume we refer to the conflict between China and Japan as the China War or the War of Resistance. This volume focuses on the period 1937-45. Other scholars also refer to the conflict as the Anti-Japanese War, the Great War, the Asian War, or the Sino-Japanese War. 


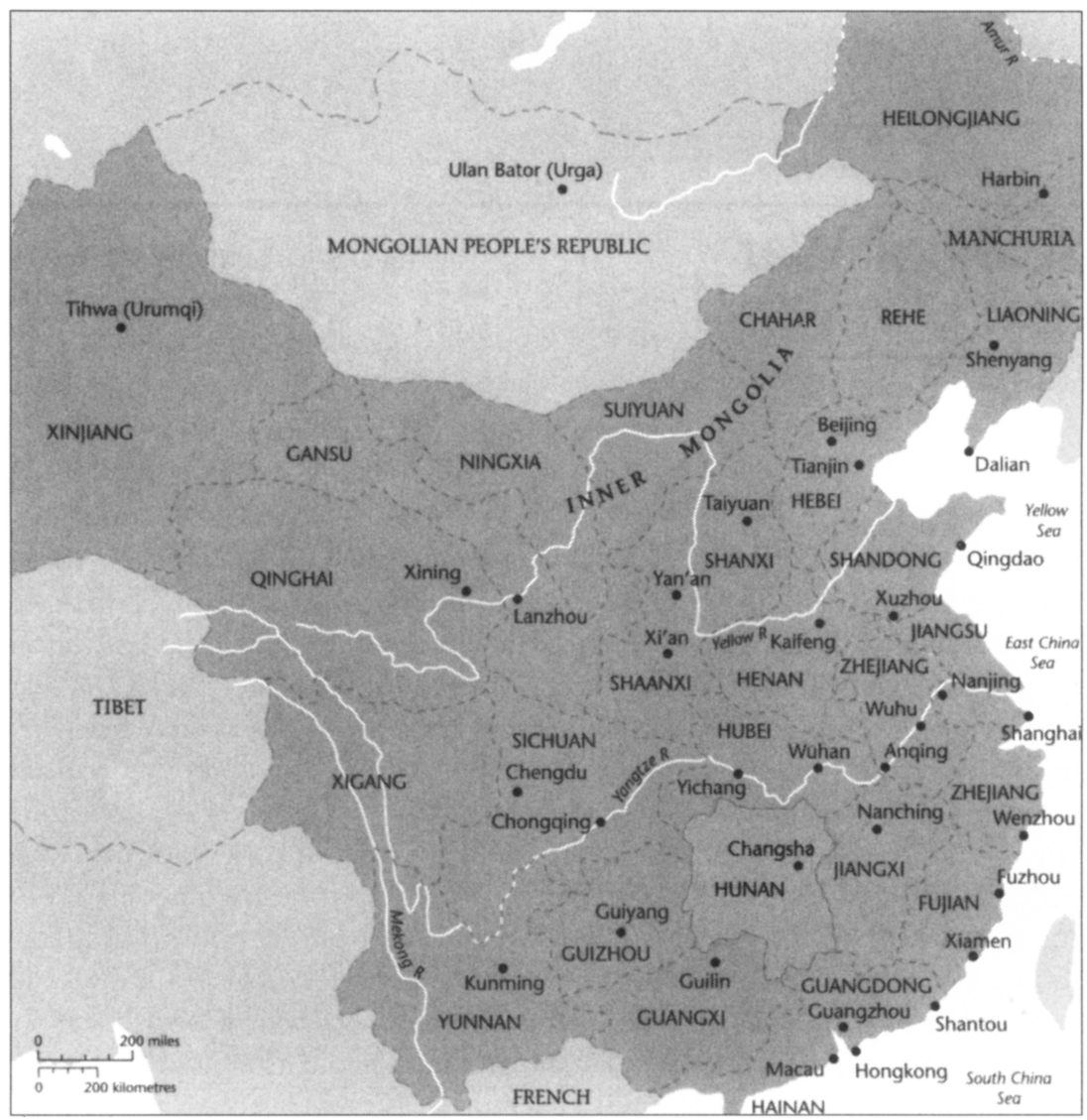

China in the I930s

less, and those who opposed any cooperation. China had been previously overwhelmed by horsemen who attacked the more settled peoples, but these conquerors then became part of the more advanced Chinese civilization. Japanese conquest was more humiliating because the Japanese came with more modern technology and more effective organization. How do the Chinese explain to themselves their weaknesses that allowed their country to be subdued by a small country on their periphery that had been learning civilization from China for more than a millennium? How do they heal the scars of the horrors of war inflicted by Japanese troops? How do they heal the rifts between those Chinese who collaborated more and those who collaborated less or not at all?

The Communists helped fan the flames of anti-Japanese sentiment and 
channel it into support not only to gain power but also to transform China from a loosely governed ancient civilization into a modern nation-state. Today it is still tempting for Chinese leaders to mobilize anti-Japanese sentiment to gain support to cope with poverty, massive underemployment, vast inequalities, and the strains of modernization without a popular mandate from a system of voting.

For the Japanese, the China War was the tragic ending of their dream of gaining Asian cooperation while bringing the benefits of modern civilization to backward countries under Japanese leadership. The dream originated almost a century earlier as Japan, more frightened of Western military power, more unified, and led by more enlightened officials who supported modernization, began to industrialize before China. The Japanese had accurately observed that China was, as Sun Yat-sen said, a "loose sheet of sand," but they vastly underestimated the potential for Chinese nationalism to grow. By the time they became aware of the power of Chinese nationalism, they had already invested heavily in China and they chose to expand their army, strengthen their weapons production, and then resort to military force. As Maruyama Masao said, the invasion of China resulted from a combination of indecisive "cowards" at the top of civilian government and "outlaws" at low levels in the military who acted on their impulse. Though the China War brought more suffering to China than to Japan, more Japanese died in the China War than in any war in history. Japanese at home were subjected to military discipline, to the loss of young men through the draft, and to shortages of food and supplies as they tightened their belts to support the war effort. With defeat came disillusionment with the military and wounded national pride. How could Japan adjust to their first military defeat in history and to the end of their ambitions? How could the Japanese explain to themselves why they should have embarked on a course that brought so much suffering in China and at home? How could Japanese who were called upon to commit inhumane acts in China explain to their children and grandchildren what they had done? Even today, it is tempting to avoid confronting the horrible details of the war and hope that the passage of time will heal the rifts with their neighbors.

As a scholar specializing in Japanese and Chinese society, I make no secret of my admiration for both Japan and China. In China, I am regularly asked why Japanese officials still go to visit Yasukuni Shrine; why Japanese textbooks say Japan "advanced into," not "invaded," China; and why the Japanese are so reluctant to acknowledge the horrors they caused. Chinese ask why the Japanese cannot apologize to Chinese and Koreans for their crimes in World War II the way Germans did to their neighbors. I am also asked how one can tell what the Japanese are really thinking when they are being so polite. 
In Japan, I am asked why the Chinese demand apologies more than half a century after the war by Japanese who were born after World War II, and why the Chinese press does not inform its people of the Japanese public's revulsion to militarism after World War II, of Japanese contributions to global peace, and of the scope of its financial and technological assistance to China. Japanese ask why Chinese children who grew up after the war are still taught to hate the Japanese, and if there is any way to help Chinese overcome their hatred of Japanese.

As an administrator in East Asian studies at Harvard (directing the East Asian Research Center in the mid-I970s, the U.S.-Japan Program in the early I980s, and the Fairbank Center and the Asia Center in the late I990), it was my responsibility to play my part in helping advance the field of East Asian studies. At our centers, in addition to providing fellowships, we have organized conferences and publications to promote disciplinary studies of East Asia and increase knowledge about relatively neglected topics.

By any standards, the China War is one of the most neglected periods in modern East Asian studies. Some scholars have begun to take an interest in how the history of that war is viewed and reinterpreted. There have been studies of the diplomacy around the China War, of Chinese Communist base areas, of relations between the Guomindang and the Communists. But few conferences had been held on the nature of the war itself. My commitment to bringing together Japanese, Chinese, and Western scholars to study the China War stemmed from my sense of the deep sentiments that separated the Chinese and Japanese and my hope that scholars working together to gain objective understanding could contribute not only to scholarship but also to the healing of historical wounds.

Scholars seeking to understand the China War confront frustrating barriers: the lack of availability of crucial materials, linguistic difficulties, and intellectual frameworks that do not easily transcend national and disciplinary boundaries. To transcend these barriers, we need scholars in each country who are prepared to join scholars elsewhere to broaden the scope of issues we raise, to share our materials and research findings, and to strive to achieve a common objective understanding of what actually happened.

Several years ago, in Japan, a conference was held between Chinese and Japanese scholars to examine what happened in World War II. Both Chinese and Japanese scholars present at the conference reported that the presentations became so polarized and acrimonious that there was little real academic exchange. I believed that if Westerners organized such a conference, it might provide a more neutral setting that would enable Chinese and Japanese as well as Western scholars to engage in academic discussion. I began to make plans for such a conference. 
It would be naïve to think that a work of scholarship can by itself greatly advance the healing process between the two nations. But there are political leaders and media spokesmen in both countries who recognize the need for people in their nations to work together. We hope that our progress toward a more objective common understanding of the China War will encourage and assist them in their efforts.

At a planning conference hosted by Kato Mikio at the International House of Japan in January 2000, senior Chinese scholars (including Yuan Ming, Zhang Baijia, Zhang Tuosheng, and Jia Qingguo), senior Japanese scholars (including Hosoya Chihiro, Kitaoka Shin'inchi, Makoto Iokibe, Hata Ikuhiko, Tanaka Akihiko, and Takagi Seiichiro), and senior Western scholars (including Akira Iriye, Michel Oksenberg, Joshua Fogel, Warren Cohen, and Nancy Tucker) gave us encouragement and advice about how we might proceed to bring together scholars from China, Japan, and the West to look at the China War. At that conference, Michel Oksenberg suggested that a basic intellectual perspective that would advance understanding of the China War was regional variation. Because of China's size and the variations of circumstances in different localities, this seemed to be an important starting point for studying the China War. In the last months of his life, Oksenberg took time to make many helpful suggestions to push forward this agenda. We decided to hold a conference on this topic and then produce a volume. The decisions about the structure of the conference, the topics to be covered, and the revision of papers for this volume were made entirely on academic grounds.

To provide the intellectual leadership for studying regional variations, I was able to recruit Diana Lary, a Canadian scholar, and Stephen MacKinnon, an American scholar. Lary had for many years been conducting research on Guangxi Province during the China War, and MacKinnon for many years had been studying the Wuhan area. The two had collaborated earlier to study the scars of the China War. They believed deeply in our goals of bringing together scholars beyond national boundaries to enhance our understanding of the regions. Once they took on responsibility for planning, they consulted with a broad range of intellectual leaders in China, Japan, and the West to enlist their cooperation and to prepare papers. They have been in charge of the content of the conference and editing at all stages. They undertook the painstaking task of preparing manuscripts in Chinese and Japanese for an English-reading audience.

In China, Yang Tianshi, an intellectual statesman and senior academician in the Institute of Modern History, Chinese Academy of Social Sciences (CASS), agreed to take the lead in assembling Chinese scholars who were committed to this objective scholarly enterprise. Yang, editor of Bainianqiao (Intellectual Currents of the Last Century) and former 
director of the Institute of Modern History, CASS, was convinced that understanding the full context of issues he was working on required the perspective and cooperation of Japanese scholars familiar with materials in Japanese. He made use of his broad contacts in the Chinese scholarly world to enlist the cooperation of outstanding scholars working on these issues in various universities and institutes.

In Japan, any discussion of the China War, including efforts to study it objectively, remains highly controversial. Yamada Tatsuo, a widely respected "can-do" China specialist, convinced of the need for such research, organized an advisory group of senior specialists, including Eto Shinkichi, the informal dean of Chinese studies in Japan; Hosoya Chihiro; and Hata Ikuhiko. He also organized a younger team of leading China specialists at major centers in Japan. These groups helped identify and recruit for our conference scholars engaged in research who could help prepare appropriate papers. At the time of our conference, Yamada was dean of the Keio University Law Faculty, but now he has a broader audience as professor of modern Chinese history at the University of the Air. Stimulated by our conference planning and aware of the limited Japanese scholarship on the China War, Yamada and his fellow scholars formed a new Association for the Study of the China War. This association now holds regular sessions to hear research reports, train younger scholars, share information about sources and publications, and publish a newsletter for a broader audience. The association promoted new research to prepare for our conference.

The conference was held at Harvard University in June 2002 under the auspices of the Harvard Asia Center. Although it was a closed conference to ensure a full exchange between participants, in addition to the outstanding specialists from China and Japan, an unusual array of outstanding Western specialists on modern Chinese history attended. Among those specialists were Timothy Brook, Paul Cohen, Joseph Esherick, Joshua Fogel, William Kirby, Jonathan Spence, and Frederic Wakeman Jr. Among the outstanding modern Japanese historians were Akira Iriye, Andrew Gordon, and Yang Daqing. Designated discussants all took their assignments very seriously.

All participants agreed that, despite the sensitivity of the topic and the diversity of viewpoints represented, the conference atmosphere was warm, cordial, and scholarly. All participants were forthright in presenting their views, even on controversial topics, but they also listened patiently to those with very different perspectives. We are grateful to all participants for sharing in this effort to create an international community of scholars studying one of the most painful periods of Asia's long history.

Although many scholars in other countries working on many topics are fluent in English, many of the best scholars in China and Japan doing re- 
search on the China War are not. We aimed to attract the best scholars regardless of language ability, and we knew that good scholarly exchange in a short period of time required the best possible simultaneous interpretation. We were fortunate in being able to attract a superb and dedicated group of interpreters: June Mei, Jiangzhong Mei, Reiko Farrelly, Fujiko Sato, and Satoko Utsunomiya. They made it possible to have a lively intellectual exchange throughout the conference.

Holly Angell, the conference coordinator, did an extraordinary job in assuring that all the logistics underpinning the conference went smoothly and in creating an atmosphere that allowed us to engage in serious scholarly debate about sensitive issues without personal rancor. She was ably assisted by Anna Laura Rosow, Kate Sauer, Shi Wenying, and Leslie Hassan-Seidman. The financial support for the conference and the preparation of this volume came from the United States Institute of Peace, which supports programs for resolving difficult issues between different countries and ethnic groups; from Lee Folger, a generous Harvard alumnus dedicated to promoting understanding between the United States and Asia; and from the Asia Center, the Fairbank Center, and the Reischauer Institute at Harvard University, which contributed proceeds from their endowed funds.

The able rapporteurs for the conference were Sophie Roell and Joe Wicentowski. Subsequently, Lee Mack, Lily Chang, and Adella Mikkelsen, graduate students at Harvard, provided superb assistance in editing the conference papers. Holly Angell and Lee Mack were extraordinarily patient and responsible in coordinating all the translations and editorial changes and in finalizing the papers for publication. We are also grateful to those who assisted in translating Chinese and Japanese papers into English and in translating English papers into Chinese.

The reader will notice that we have not tried to homogenize national differences in intellectual approach and style. Scholarship in China has had a didactic purpose and a penchant to emphasize the moral difference between the aggrieved party and the aggressor. But the Chinese papers in this volume also reflect the growing determination of Chinese scholars to look at the facts objectively and to try to understand the views of different parties. In Japan, because the issues of responsibility for aggression in the China War are still highly sensitive, some Japanese scholars are more comfortable providing factual informative accounts that are peripheral to some basic issues such as the nature of aggression and the extent of wartime devastation. Nor have we edited out entirely references in Western papers to concepts currently fashionable in Western scholarship. But the editors have made every effort to ensure that papers are factually correct.

Paper writers made great efforts to meet deadlines, tailor their papers to 
fit the requests of conference organizers, and make revisions in line with the conference discussion and the suggestions of Lary and MacKinnon. Although we restricted conference participation to a small group of invitees who could have intensive discussion, our goal is to assist all scholars and students who now, or will in the future, study the China War. Steven Phillips, a self-starter with great persistence, has, on our behalf and with the assistance of scholars from Japan and China, put together a comprehensive guide to materials on the China War in Chinese, Japanese, and English. We have made these available on a web page created by Steven Phillips and Oona Patrick. We plan to continue to update this website to assist scholars working in this area. The website (http://www.fas.harvard. edu/asiactr/sino-japanese/) has information about the 2002 conference; information about a subsequent January 2004 conference on the military history of the China War; links to further Chinese, Japanese, and English language materials; and a format for dialogue between scholars.

In addition to this conference and volume, the conference on the military history of the China War also had Chinese, Japanese, and Western participants. That conference was under the scholarly direction of Mark Peattie of the Hoover Institute, Stanford University. Peattie and his co-editors, Hans van de Ven and Edward Drea, are finishing revising the conference volume for publication. A third conference in the series, on education and culture, was hosted by Hirano Kenichiro and Yamada Tatuso in Hakone, Japan; and Yang Tianshi hopes to host a fourth conference in China

Much work remains to be done. It will take Westerners decades to pore over the vast number of primary documents in Chinese and Japanese. It will take courage and fortitude as well as time for Japanese scholars to spell out more fully the details about the cruelty of Japanese troops and the suffering they brought. Chinese scholars will someday provide greater depth and subtlety about how Chinese during the China War adapted to Japanese power without falling easily into the two currently correct categories, patriot or traitor. We hope this volume will stimulate progress in all these directions.

Fred Wakeman, who played a key role at the 2002 conference on China at war, became fatally ill in the summer of 2006 and died in September. As a historian, scholar, and mentor, Fred was a towering figure in Chinese studies in North America after he inherited Joseph Levenson's mantle at University of California, Berkeley, in the mid-I96os. Included in China at War is one of his last essays. We publish it with a great sense of sadness and loss.

Ezra F. Vogel 